Magna Scientia Advanced Research and Reviews

eISSN: 2582-9394

Cross Ref DOI: $10.30574 / \mathrm{msarr}$

Journal homepage: https://magnascientiapub.com/journals/msarr/

Check for updates

(RESEARCh ARTicle)

\title{
Assessment of Building Coverage and Environmental Quality of Residential Area in Nkpor Uno Idemili North Local Government Area, Anambra State, Nigeria
}

\author{
Aronu Cecilia Nkechi 1, Ede Alison Okorie 1, *, Ilo Clementine Ifeyinwa 2, Okeke Monique Ugochinyere 1, \\ Nwankwo Chidiebere Joy 1, Adaeze EChukwudebelu 1, Mbaegbu Nnamdi Okwudili 3, Nwazunku Augustine \\ Alugbala ${ }^{1}$, Odupute Colman $\mathrm{N}^{4}$ and Obasi Kalu Ojo ${ }^{1}$ \\ ${ }^{1}$ Department of Environmental Health Science. Faculty of Health Sciences and Technology, Nnewi Campus, Nnamdi Azikiwe \\ University, Anambra State. \\ 2 Department of Nursing Science. Health Science. Faculty of Health Sciences and Technology, Nnewi Campus, Nnamdi \\ Azikiwe University, Anambra State. \\ 3 Surveillance and Epidemiology Department, Nigeria Centre for Disease Control, Abuja, Nigeria. \\ ${ }^{4}$ Department of Radiology, Kogi State University Teaching Hospital, Dekina, Kogi State, Nigeria.
}

Magna Scientia Advanced Research and Reviews, 2021, 03(01), 019-024

Publication history: Received on 13 August 2021; revised on 23 September 2021; accepted on 25 September 2021

Article DOI: https://doi.org/10.30574/msarr.2021.3.1.0066

\begin{abstract}
This study was conducted to assess the building coverage and environmental quality of residential area in Nkpor Uno Idemili North L.G, Nigeria. The study employed a descriptive survey design to find out level of compliance of buildings to planning regulations. One hundred and eighty (180) were interviewed using a modified instrument (questionnaire). The data collected were coded into SPSS and analyzed with descriptive statistics. The results showed that $72(40 \%)$ reported inadequate setback as a major effect of over built buildings, 55(30.6\%) reported inadequate free air space, $37(20.6 \%)$ said inadequate ventilation and lighting. Also, the nature of drainage system provided in residential areas; $76(42.2 \%)$ has no drainage system, $70(38.9 \%)$ has close drainage system. The building coverage of residential houses in the study area; $60(33.3 \%)$ has their building falls under $51-75 \%$ for over built, $48(26.7 \%)$ has their building falls under $76-100 \%$ for overbuilt. For the factors influencing the percentage of area built upon, $57(31.7 \%)$ has greed and no money to acquire a large plot of land, $47(26.0 \%)$ has no land space to built their desirable house. Then, non adherence to provision of adequate ventilation and lighting in the residential houses in the study area affects the dwellers' health and such factors can promote communicable diseases. In conclusion, it was observed that the compliance rate was not encouraging because the planning regulations recorded very low compliance as include set-back from property boundaries; inadequate free air space; lost of aesthetic values, and inadequate ventilation and lighting. Therefore, government should embark on enforcement of land use plan, and strategic plans for various towns and villages to accommodate its utilities and facilities.
\end{abstract}

Keywords: Building, Coverage, Environment, Resident; Idemili North

\section{Introduction}

Building coverage is an important and fundamental component of the overall activities performed on land in both rural and urban areas. Due to the movement of people into urban areas, the national population increase and inadequate responses by the government have contributed to the appealing situation in the country and it affects economic development and welfare of the citizen [1, 2 \& 3].

\footnotetext{
*Corresponding author: Ede Alison Okorie

Department of Environmental Health Science. Faculty of Health Sciences and Technology, Nnewi Campus, Nnamdi Azikiwe University, Anambra State.
}

Copyright (C) 2021 Author(s) retain the copyright of this article. This article is published under the terms of the Creative Commons Attribution Liscense 4.0. 
In respect to the above, building condition which is characterized by the type of construction and materials used, as well as the location and age of the building, may affect indoor environmental quality (IEQ). In some studies conducted by Furuya and Takahashi [4] and Boulanger et al [5] opined that buildings with certain materials, such as aluminum composite material (AMC), may contribute to building occupants' exposure to asbestos. In addition, especially older school buildings may have flaking asbestos ceiling tiles and other materials containing asbestos [6]. Buildings may also have leaky parts enabling mold and bacterial growth [7]. Building facilities such as basements have greater risk factors such as dampness and mold, while some buildings located near sources of pollution such as mines, factories and incinerators are exposed to perennial air pollution $[8,9,10]$.

Following the effect of building quality in Nigeria, it has been observed that rapid population and rural urban migration have compounded the problems of substandard building coverage due to commercialization in Nigeria especially in Nkpor Uno, Anambra state. Having observed fast increase in economic development, it leads to demand on housing stocks which resulted to high rate of land use, rents, development of slum settlement and substandard building. Also, they have serious impact on the built environment and serious consequences on health of the residents $[11,12]$

The quality of a residential environment in most rural-urban developing environment is deplorable. Mabogunje [13], stated that building quality is not only dependent on the material characteristics of the buildings but on their organization as spatial unit.

Wahab et al [14], and Olotuah, [12] reported that seventy five percent of the dwelling unit in Nigeria's urban centre are substandard due to the consequence of non-compliance with building laws and regulations. The dangers of noncompliance with relevant building laws are; the danger in violation of setback standard and the problem of density, the acceptable site coverage is $50 \%$ for residential building in high density area, $40 \%$ for medium density area, $30 \%$ is acceptable in low density area, but greedy developers hardly comply with building laws and regulations especially in high density area. They can make use of $70 \%$ of the site and the consequences of such are overcrowding and inadequate parking space [15].

The main reason behind public regulation of land use was to promote public health, safety, moral protection and welfare specially, zoning which prevents overcrowding. Maintained property values and encouraged stable and homogenous neighborhoods. It also ensures security for children, fire and types safety residential area [16].

The built environment in many developing countries particularly Anambra is fact degenerating due to its commercialization. The factors responsible for this can be attributed to rapid urbanization, rural-urban migration and decades of steady economic downturn, decay of urban infrastructure and poor housing quality [17].

In relation to the studied area (Nkpor), one of the major commercial cities in Anambra State, Nigeria has been experiencing rapid urbanization; the level of population growth of the place contributed to expansion of the area with a lot of building coverage. Housing design and development has been neglected and yet such housing designs are very important. Urban planners and designers have not taken much action to shape the environment into designed areas where people can live comfortably and enjoy the highest possible quality of life. Therefore, this study aimed to assess the building coverage and environmental quality of residential area in Nkpor Uno Idemili North L.G, Nigeria.

\section{Material and methods}

A descriptive survey research design was adopted for the study in order to assess the building coverage and environmental quality of residential area in Nkpor Uno Idemili North L.G, Nigeria. It was considered appropriate for the study because it permitted the description of the condition as they are in the natural state [18]. This study was carried out in Nkpor Uno, Idemili North local government Area of Anambra state Nigeria.

A systematic sampling technique was used to draw out the sample size of 180 needed for the investigation through administration of questionnaire. The five villages in Nkpor-Uno were selected and used for the study. In each village, 36 household were assessed systematically.

The research instrument used was an observational check list and it was validated by research supervisor in where the content and language used were correct enough to achieve the stated objective. The analysis of information collected was analyzed using descriptive statistics. 


\section{Results}

Table 1 shows the analyzed data from respondents on the building coverage and environmental quality of residential area in Nkpor Uno,Idemili North L.G.A;the results showed that 72(40\%) reported inadequate setback as a major effects of over built buildings followed by $55(30.6 \%)$ that reported inadequate free air space, $37(20.6 \%)$ said inadequate ventilation and lighting while $16(8.8 \%)$ said that such buildings gave unaesthetic nature to the environment.

Table 1 The effects of over-built buildings in residential areas

\begin{tabular}{|l|c|c|}
\hline Variables & Frequency & Percentage \\
\hline Inadequate setback & 72 & 40.0 \\
\hline Inadequate free air space & 55 & 30.6 \\
\hline Lost of aesthetic values & 16 & 8.8 \\
\hline Inadequate ventilation and lighting & 37 & 20.6 \\
\hline Total & 180 & 100 \\
\hline \multicolumn{2}{|r|}{ Source:Field survey (May 2020) } \\
\hline
\end{tabular}

Table 2 depicted on the nature of drainage system provided in residential areas; $76(42.2 \%)$ has no drainage system, $70(38.9 \%)$ has close drainage system while $34(18.9 \%)$ has open drainage system.

Table 2 Nature of drainage system provided in residential areas

\begin{tabular}{|l|c|c|}
\hline Variables & Frequency & Percentage \\
\hline Closed drainage & 70 & 38.9 \\
\hline Open drainage & 34 & 18.9 \\
\hline None of the above & 76 & 42.2 \\
\hline Total & 180 & 100 \\
\hline \multicolumn{2}{|r|}{ Source:Field survey (May 2020) } \\
\hline
\end{tabular}

Table 3 presented the building coverage of residential houses in the study area; $60(33.3 \%)$ has their building falls under $51-75 \%$ over built, $48(26.7 \%)$ has their building falls under $76-100 \%$ overbuilt, $42(23.3 \%)$ has their building falls under 26-50\% not overbuilt while $30(16.7)$ has their building falls under $0-25 \%$ not overbuilt.

Table 3 Building coverage of residential houses

\begin{tabular}{|l|c|c|}
\hline Building coverage in percentage of area built upon & Frequency & Percentage \\
\hline $0-30 \%$ for low density area (not overbuilt) & 30 & 16.7 \\
\hline $31-50 \%$ for medium density (acceptable built) & 42 & 23.3 \\
\hline $51-75 \%$ for high density area (over built) & 60 & 33.3 \\
\hline $76-100 \%$ for high density area (beyond over built) & 48 & 26.7 \\
\hline Total & 180 & 100 \\
\hline \multicolumn{2}{|c|}{ Source:Field survey (May 2020) } \\
\hline
\end{tabular}

Table 4 showed the factors influencing the percentage of area built upon, the result shows that $57(31.7 \%)$ has greed and no money to acquire a large plot of land, $47(26.0 \%)$ has no land space to built their desirable house, 39(21.7\%) never wants to leave the land of inheritance from the parents, while 37(20.6\%) has belief and culture not to leave their family property. 
Table 4 Factors influencing the percentage of area built upon

\begin{tabular}{|l|c|c|}
\hline Factors & Frequency (n) & Percentage \% \\
\hline Land & 47 & 26.0 \\
\hline Inheritance from parents & 39 & 21.7 \\
\hline Greed and Money & 57 & 31.7 \\
\hline Belief and culture & 37 & 20.6 \\
\hline Total & 180 & 100 \\
\hline
\end{tabular}

\section{Discussion}

The findings of this study titled assessment of building coverage and environmental quality of residential area in Nkpor Uno Idemili North L.G, Nigeria showed the level of compliance of buildings to planning regulations is not significant. The compliance rate was not encouraging because the planning regulations which recorded very low compliance as include set-back from property boundaries; inadequate free air space; lost of aesthetic values, plot coverage; plot size; and inadequate ventilation and lighting. This result implies that development control activities of the planning authorities have failed to deliver a sustainable and functional built environment, and therefore needs to be re-examined. It also means that timely intervention in the suburban/rural areas to correct these planning aberrations through preparation and implementation of planning schemes would be of great benefit. The study ascertained factors which are responsible for the low level of compliance to planning regulations as follows: low level of physical planning; inadequate funding for planning authorities; enforcement risks; high cost of approval fees; court cases; and interference by the political class [16].

From the findings of the study, it was agreed with the research carried by Owueye and Ogunduiran [19] who found out that the environmental and housing quality in some urban area has negative effect on physical environment and the result also shows the level of congestion, poor state of road and building.

In regard to environmental qualities of the buildings inresidential areas; the results indicated majority had drainage system and greater number of the available ones was closed. The finding was in line with Misztal and Kuczera [20] who found out the negative impact on survey water quality supply from residential built up area, which has no regular water quality supply neither sewage disposal system nor drainage system.

In terms of factors influencing the percentage of area built upon in the study such as greed and no money to acquire a large plot of land, no land space to build their desirable house, never wants to leave the land inheritance from the parents, and believe and culture not to leave their family property. All these were not far a study carried out by Ahianbas, Dimuna and Okogun [15] who found out that residential building in high density area where greedy developers built as much as $70 \%$ (or more than) of the site.

The owners/developers of the buildings in the study area had failed to comply with the relevant building laws and to consider the followings; firstly, building along utility linemay be demolished by government in future time if there is need for constructions or destruction of public utilities. Secondly, building and creating space between them, and enhancing set back zoning, may also causes throwing water into another premises and it affects the aesthetic of the environmental quality.

Therefore, non adherence to provision of adequate ventilation and lighting in the residential houses in the study area affects the dwellers' health and it's also one of the factors that promote communicable diseases.

\section{Conclusion}

The findings of the study revealed that residential building in the study area where over built, they could caused inadequate set back, inadequate free air space, and inadequate ventilation and lighting in the study area. Thus to improve in building and environmental quality, relevant government authorities should ensure and enforce the compliance of building laws by the developers. 


\section{Recommendations}

The study therefore recommends government should embark on enforcement of land use plan, and strategic plans for various towns and villages to accommodate its utilities and facilities. There should be regular monitoring of building compliance before and during erecting of a building.

\section{Compliance with ethical standards}

\section{Acknowledgments}

The authors are grateful to leaders of residential area in Nkpor Uno Idemili North L.G who assisted and permitted in administering questionnaire and collection of data for this study. The authors express profound appreciation to the Provost of the School Health Technology Obosi that participated for their cooperation in providing enabling environment for the research work.

\section{Disclosure of conflict of interest}

All authors of this article report no conflicts of interest throughout the work.

\section{References}

[1] Federal Republic of Nigeria. Official Gazette on The Breakdown of the National and State Provisional Totals 2006 Census, S.I N0 23 Of 2007, N0.24,.94 Lagos. 15th May, 2007.

[2] Akinmoladun OI,Oluwoye J. An Assessment of Why the Problems of Housing Shortages Persist in Developing Countries: A Case Of Study Of Lagos Metropolis, Nigeria Pakistan Journal Of Social Science. 2007; 4(4): 589-598.

[3] Ademiluyi AI, Raji BA. Public and Private Developers as Agents in Urban Housing Delivery in Sub-Saharan Africa: The Situation in Lagos State. Humanity \& Social Sciences Journal. 2008; 3(2): 143-150.

[4] Furuya S, Takahashi K. Experience of Japan in Achieving a Total Ban on Asbestos. Int J Environ Res Public Health. 2017;14(10):12-61.

[5] Boulanger G, Andujar P, Pairon J-C, et al. Quantification of short and long asbestos fibers to assess asbestos exposure: a review of fiber size toxicity. Environ Health. 2014;13(1):59.

[6] Flynn E, Matz P, Woolf A, Wright R. Indoor air pollutants affecting child health. A Proj Am Coll Med Toxicol. 2000.

[7] Othman NL, Jaafar M, Harun WMW, Ibrahim F. A case study on moisture problems and building defects. ProcediaSocial Behav Sci. 2015; 170:27-36.

[8] Cho SJ, Cox-Ganser JM, Park J. Observational scores of dampness and mold associated with measurements of microbial agents and moisture in three public schools. Indoor Air. 2016; 26(2):168-178.

[9] Toyinbo O, Matilainen M, Turunen M, Putus T, Shaughnessy R,Haverinen-Shaughnessy U. Modeling associations between principals' reported indoor environmental quality and students'self-reported respiratory health outcomes using GLMM and ZIP models. Int J Environ Res Public Health. 2016;13(4):385.

[10] Porta D, Milani S, Lazzarino AI,Perucci CA,Forastiere F. Systematic review of epidemiological studies on health effects associated with management of solid waste. Environ Health. 2009;8(1):60.

[11] Onibokun P. Housing in Nigeria, NISER, Ibadan 1985, Kwanshie. Housing and Urban Development. 2003.

[12] Olotuah A. Accessibility of Low-Income Earners to Public Housing in Ado-Ekiti, Nigeria.Civil and Environmental Research. 2015; 7(7):1- 6.

[13] Mabogunje A. I. An African Perspective. In UN-HABITAT Debate. 2004; 10(4): 12.

[14] Wahab B. Indigenous knowledge and development process. Lead paper presented at the First Ibadan Sustainable Development Summit organized by the Centre for Sustainable Development, University of Ibadan held at the Conference Centre, University of Ibadan. 5 November 2010.

[15] Ahianba JR, Dimuna KO,Okogun GRA. Built environment Delay and Urban Health in Nigeria. 2008.

[16] Ogbonna CG, Obinka AN,Aguguo GU. Property Development and Land Use Planning Regulations in Nigeria. International Journal of Environment, Agriculture and Biotechnology (IJEAB). 2017; 2(4): 1694-1707. 
Magna Scientia Advanced Research and Reviews, 2021, 03(01), 019-024

[17] World Bank. Housing: Enabling Markets to Work with Technical Supplement. 1993.

[18] Nworgu BG. Educational Research; Basic Issues and Methodology. Windon Publishers Ltd., Ibadan. 2006.

[19] Owoeye J0,Ogunduran AO. A study on Housing and environmental Quality of Moniya community in Ibadan, Nigeria. 2015.

[20] Misztal A,Kucsera M. An Impact Assessment of Built up residential area on selected water Quality. 2008. 